\title{
O „POŻERANIU WLASNYCH DZIECI” NA PRZYKŁADZIE DZIAŁALNOŚCI PARTII KOMUNISTYCZNYCH W POLSCE W XX WIEKU
}

\begin{abstract}
Przedmiotem artykułu jest zjawisko usuwania z życia politycznego przywódców i polityków partii komunistycznych w Polsce w różnych okresach ich działalności. W przypadku Komunistycznej Partii Polski (1918-1938) i Polskiej Zjednoczonej Partii Robotniczej (1948-1990), podmiotów badań, chodziło o eliminację niejako „najwierniejszych z wiernych” i to przez towarzyszy z tego samego środowiska politycznego. Stwierdzić trzeba, że problem „pożerania własnych dzieci” był znany w historii, występuje współcześnie i będzie obecny w przyszłości. W przypadku partii komunistycznych na zjawisko „,pożerania własnych dzieci” wpływ miały różne okoliczności: 1) przede wszystkim specyfika partii komunistycznych: (były to partie fundamentalistyczne; KPP działała nielegalnie w oparciu o model partii-zakonu), 2) podległość suwerenowi zewnętrznemu, który miał decydujący wpływ na styl politycznego myślenia i działania, 3) procesy, którym podlegały, tj. funkcjonowanie w warunkach syndromu oblężonej twierdzy i zapotrzebowania na wroga, który pozwalał realizować różne cele wewnątrz i na zewnątrz partii, 4) brutalna walka o władzę, która, w przypadku PZPR, przez cztery dekady sprawującej władzę polityczną w Polsce, pozwoliła korzystać oprócz wsparcia zewnętrznego także z aparatu państwa.
\end{abstract}

Słowa kluczowe: ,pożeranie własnych dzieci”, rewolucje, partie komunistyczne, herezje, walka o władzę.

\section{WPROWADZENIE}

Zjawisko usunięcia z życia partyjnego przywódców i działaczy komunistycznych w Polsce przez towarzyszy z tego samego środowiska politycznego wystąpiło w kilku okresach istnienia partii komunistycznych: w latach 20. i 30. XX wieku dotknęło aktywistów Komunistycznej Partii Polski (1918-1938), w latach 40., 50., i 60. Polskiej Zjednoczonej Partii Robotniczej (1948-1990) i aparatu władzy Polski Ludowej. Chodziło o eliminację z życia politycznego w dużej mierze niejako „najwierniejszych z wiernych”, twórców i czołowych aktywistów partii oraz w części członków ich rodzin.

Problem „pożerania własnych dzieci” jest znany z historii, występuje współcześnie i będzie obecny w przyszłości. Tytułowe sformułowanie jest motywem dwóch obrazów o tytule „Saturn pożerający swego syna”: Petera Paula Rubensa z 1636 roku oraz Francisco Goyi z serii czarnych obrazów malowanych w latach 1819-1823, przedstawiających

\footnotetext{
${ }^{1}$ Prof. dr hab. Krystyna Trembicka, Wydział Politologii, Uniwersytet Marii Curie-Skłodowskiej w Lublinie; Plac Litewski 3, 20-080 Lublin; e-mail: krystynatrembicka@wp.pl

Prof. Krystyna Trembicka, DSc, PhD, Faculty of Political Science, Maria Curie-Skłodowska University in Lublin; Plac Litewski 3, 20-080 Lublin; e-mail: krystynatrembicka@wp.pl
} 
Saturna, jednego z bogów w mitologii rzymskiej, który pożarł syna. Saturn najpierw pokonał ojca Coelusa, a następnie dzieci bezpośrednio po ich przyjściu na świat, co miało pomóc w zdobyciu i utrzymaniu władzy nad światem.

Wydaje się, że ,pożeranie własnych dzieci” w świadomości społecznej najczęściej kojarzone jest z okrucieństwem rewolucji, która - w miarę przechodzenia przez kolejne, coraz bardziej radykalne fazy - godziła w jej pomysłodawców, spychając ich w niebyt polityczny bądź odbierała życie. Mogli przekonać się o tym przywódcy wielu rewolucji oraz ruchów politycznych. Historia zna wiele przykładów zwalczania, represji a ostatecznie śmierci zarówno jednostek jak i dużych grup ludzi, którzy funkcjonując w radykalnych środowiskach politycznych dokonywali wraz z nimi daleko idących zmian owocujących m.in. represjami wobec dużych grup społecznych i towarzyszy walki, a następnie sami byli represjonowani.

Georges Danton, Maximilian Robespierre, Camille Desmoulins odegrali kluczową rolę w pierwszej i drugiej fazie rewolucji francuskiej. Najbardziej znani byli dwaj pierwsi. Danton stał się sławny i zdobył uznanie paryżan dzięki wystąpieniom w Zgromadzeniu Narodowym, w którym potępiał niesprawiedliwość i korupcję, opowiedział się za karą śmierci dla króla Ludwika XVI. W okresie rządów jakobinów był jednym z inicjatorów utworzenia Trybunału Rewolucyjnego do walki z wrogami państwa i, jako jeden z przywódców radykalnego skrzydła rewolucji, był odpowiedzialny za rozpętanie terroru. Następnie stał się ofiarą towarzyszy walki, zginął bowiem z rozkazu jeszcze bardziej radykalnych towarzyszy, kierowanych przez Maximiliana Robespierre'a, którzy po kilkunastu miesiącach sami zostali zgładzeni. Podobne zjawisko można obserwować w okresie rewolucji bolszewickiej. Towarzysze Włodzimierza Illicza Lenina, lidera bolszewików, zaangażowani w zwycięstwo rewolucji i współtworzący podstawy totalitaryzmu w Rosji, a następnie umacniający system zostali zgładzeni przez Józefa Stalina, przywódcę ZSRR. W ZSRR dyktator cyklicznie przygotowywał się do rozprawy z kolejną częścią establishmentu, tak samo jak on odpowiedzialnych za zbrodnie.

Problem mordowania przeciwników politycznych obecny jest w literaturze. Dość wspomnieć o powieści George Orwella pt. Folwark zwierzęcy, w których zostały pokazane mechanizmy rządzące każdym społeczeństwem w dobie i po rewolucji, kiedy ci co angażowali się w obalenie starego systemu byli eliminowani przez swoich następców.

W przypadku partii komunistycznych na zjawisko ,pożerania własnych dzieci” wpływ miały różne okoliczności: 1) przede wszystkim specyfika partii komunistycznych: (były to partie fundamentalistyczne; KPP działała nielegalnie w oparciu o model partii-zakonu), 2) podległość suwerenowi zewnętrznemu, który miał decydujący wpływ na styl politycznego myślenia i działania politycznego, 3) procesy, którym podlegały, tj. funkcjonowanie w warunkach syndromu oblężonej twierdzy i zapotrzebowania na wroga, który pozwalał realizować różne cele wewnątrz i na zewnątrz partii, 4) brutalna walka o władzę, która, w przypadku PZPR, przez cztery dekady sprawującej władzę polityczną w Polsce, pozwoliła korzystać oprócz wsparcia zewnętrznego z całego aparatu państwa.

\section{UWARUNKOWANIA ZJAWISKA „POŻERANIA WŁASNYCH DZIECI”}

KPP i PZPR były partiami niesuwerennymi. Suweren zewnętrzny, w postaci najpierw Wszechrosyjskiej Komunistycznej Partii (bolszewików), a następnie Komunistycznej Partii Związku Radzieckiego, decydował o obliczu ideowym partii i ewolucji myśli politycznej. Poza tym rząd radziecki finansował partie komunistyczne w okresie międzywojennym, co 
dodatkowo je uzależniało. Od drugiej połowy lat 20. XX wieku do zależności materialnej doszła jeszcze zależność policyjna.

Inspiracją dla ruchu komunistycznego była Międzynarodówka Komunistyczna. MK powstała z inicjatywy W.I. Lenina 2 marca 1919 roku w celu kontroli, koordynowania i wspierania działań wszystkich partii komunistycznych. Ich zadaniem było prowadzenie działań na rzecz przejęcia władzy w państwie ${ }^{2}$. Ważną rolę odgrywało pismo „Kommunisticzeskij Internacyonał” (Międzynarodówka Komunistyczna), w którym zamieszczano decyzje MK, analizowano sytuację międzynarodową, interpretowano aktualnie obowiązującą strategię i taktykę, określano wrogów i sojuszników, zarówno na zewnątrz jak i wewnątrz ruchu komunistycznego. Poprzez pismo udało się stworzyć jedność poglądów w całym ruchu komunistycznym. W latach 40. i 50. XX wieku analogiczną rolę odgrywało Biuro Informacyjne a po 1956 roku narady partii komunistycznych i robotniczych.

Komuniści nie mieli swobody w wytyczaniu założeń strategicznych i taktycznych. Wiara w słuszność linii WKP(b) urosła do rangi dogmatu już w latach 20. Rezultatem był brak samodzielnego myślenia, bezkrytyczne przyjmowanie ocen i wniosków MK. Ewentualny błąd, będący niezgodną z wytycznymi MK oceną jakiegoś wydarzenia, musiał owocować samokrytyką, wyznaniem ,winy”, czyli często potępieniem tego, co wcześniej nie było błędem. Komuniści podkreślali nieomylność „klasyków marksizmu” w czasach, kiedy pisali i działali. Prawo zmieniania sądów wyrażanych przez Fryderyka Engelsa i Karola Marksa, twórcom doktryny komunistycznej przyznawali wyłącznie ich następcom - Leninowi i Stalinowi. „W ten sposób marksizm - konstatował Jerzy Holzer - jako nauka miał zachować charakter prawdy absolutnej i globalnej, ale zarazem zmieniać się stosownie do rozwoju wydarzeń"3. O ile oficjalnej wykładni marksizmu zawsze dokonywał wódz, którym był przywódca WKP(b)/KPZR, o tyle jej czystości w poszczególnych sekcjach, a następnie w państwach demokracji ludowej przestrzegali i pilnowali „namaszczeni” przez moskiewskie centrum decyzyjne lokalni przywódcy. Partyjni uczeni wspierali rządzących, uzasadniając ich decyzje, od czasu do czasu domagali się oczyszczenia partii i „nauki” marksistowskiej ,z chwastów”4. Czystość ideologiczna i polityczna miała być jedynym skutecznym zabezpieczeniem się przed działalnością wroga wewnętrznego. Stwierdzić należy, że partie fundamentalistyczne, a do takich należały partie komunistyczne, miały niejako wpisaną w swoje funkcjonowanie skłonność do napiętnowania wszystkich, którzy wyrażali jakąkolwiek krytykę czy tylko wątpliwość co do zawartych w ,świętych” księgach rozstrzygnięć ideologicznych.

Istniejące w Polsce KPP i PZPR były partiami stalinowskimi. Charakteryzowały je skrajna centralizacja, dyscyplina i posłuszeństwo. Dyscyplina wyrażała się w grupowych normach moralnych, obyczajowych, światopoglądowych, nakazach i zakazach, regulujących te dziedziny życia osobistego, które były poza obszarem uczestnictwa w partii w ścisłym tego słowa znaczeniu. Stefan Staszewski, funkcjonariusz partyjny działający w Zagłębiu Dąbrowskim, na Śląsku i w Łodzi, w odpowiadając na pytanie Teresy Torańskiej komunistę określił, jako człowieka bezwzględnie wierzącego partii: „Bezwzględnie, czyli wierzący jej bezkrytycznie na każdym etapie, niezależnie od tego, co ta partia głosi. Człowiek posiadający przystosowawczą zdolność umysłu i sumienia do przyjmowania bez

2 W.I. Lenin, Tezy na II Kongres Międzynarodówki Komunistycznej [w:] W.I. Lenin, Dzieła wszystkie, t. 41, Warszawa 1988, s. 198.

3 J. Holzer, Komunizm w Europie. Dzieje ruchu i systemy władzy, Warszawa 2000, s. 9.

${ }^{4}$ II Zjazd PZPR, Warszawa 1954, s. 342 (wystąpienie Adama Schaffa). 
zastrzeżeń dogmatu, że partia się nie myli, choć myli się bez przerwy, co zresztą sama na każdym nowym etapie przyznaje. Nowy etap właściwie zaczyna się od krytyki poprzedniego i zapowiedzi, że dotąd się wprawdzie myliła, ale teraz przestaje. Kto potrafi w sobie pogodzić tę sprzeczność czy mówiąc po marksistowsku ten proces dialektyczny: nieomylność i omylność partii - jest komunistą"5. I rzeczywiście komuniści byli wyjątkowo „elastyczni”, gdy chodziło o zmianę własnych poglądów. Dobrym przykładem może być postać Juliana Leszczyńskiego-Leńskiego, przywódcy KPP w latach 30. XX wieku. Do lat 1934-1935 był wielkim zwolennikiem, przy pełnym udziale MK, radykalnych metod działania, jednoznacznie klasyfikował wrogów i był wyjątkowo pryncypialny w realizacji obowiązujących wówczas założeń strategicznych i taktycznych. Już po dwóch latach zmienił poglądy, w dodatku na wcześniej przez siebie zwalczane. Rację miał Grzegorz Zackiewicz uznający, ,że druga połowa lat 30. stanowiła okres, w którym swoista polityczna schizofrenia (...) osiągnęła apogeum”. Oto „totalitarna formacja, jaką była KPP, niemal z dnia na dzień - w myśl dyrektyw płynących z Moskwy - zaczęła głosić hasła obrony demokracji"'6.

Komuniści, zarzucający wielokrotnie władzom polskim łamanie zasad demokracji i praworządności, sami nie mieli zamiaru zabiegać o poparcie społeczne dla lansowanych rozwiązań ustrojowych, a jednocześnie w dość specyficzny sposób postrzegali przeciwników politycznych: przekonanie o konieczności ich zniszczenia, a w najlepszym razie wykorzystania. Bezkompromisowość i chęć zniszczenia przeciwnika, moralnego i fizycznego, odegrały istotną rolę w ,pożeraniu własnych dzieci”.

Ważną częścią komunistycznego stylu myślenia był dogmatyzm. Jego skrajną formą były poglądy uznawane za „,sekciarskie”, czy „ultralewicowe”, „lewackie”. Ich sens sprowadzał się do działania na rzecz jak najszybszego przejęcia lub umocnienia władzy bez względu na koszty. W okresie międzywojennym charakteryzował się taktyką preferującą bezpośrednią walkę o władzę i ustanowienie „dyktatury proletariatu” oraz potępieniem działania na rzecz reform w państwie polskim, np. mających na celu chociażby poprawę bytu robotników. Niewątpliwie były to poglądy zupełnie rozmijające się z odczuciami szerokich grup społecznych oraz działania wykluczające możliwość realizacji celu. Poglądy „,sekciarskie” mieściły w sobie tendencję szukania przyczyn trudności czy porażki w poczynaniach przywódców, ich rodowodzie politycznym, a nie w obiektywnych okolicznościach.

KPP, ale także i PZPR w pierwszym okresie istnienia funkcjonowały w warunkach istnienia syndromu „oblężonej twierdzy”. O syndromie „oblężonej twierdzy” w kontekście postawy działaczy KPP pisał Paweł Samuś. Sposób myślenia i działania komunistów był częścią szerszego zjawiska, charakterystycznego przede wszystkim dla tzw. ruchów mniejszościowych, czyli nieposiadających szerszego poparcia w społeczeństwie.

Objawami syndromu ,oblężonej twierdzy”, zwłaszcza w postawach tzw. zawodowych rewolucjonistów były m.in. wyobcowanie społeczne, jako konsekwencja statusu „wiecznych konspiratorów"; skłonność do podejmowania arbitralnych decyzji, podejrzliwość, skrytość i wzmożona czujność; tworzenie psychozy strachu; dogmatyzm i fanatyczna wiara w bliski przewrót społeczny; mitologizowanie rzeczywistości radzieckiej, która sprzyjała

\footnotetext{
5 T. Torańska, Oni, Warszawa 1989, s. 337-338.

${ }^{6}$ G. Zackiewicz, Polska myśl polityczna wobec systemu radzieckiego 1918-1939, Kraków 2004, s. 755.
} 
kształtowaniu się autorytarnej podległości, bezkrytycznego podporządkowania się autorytetom narzuconym ich partii i międzynarodowemu ruchowi komunistycznemu; przekonanie o działalności w warunkach „strefy przyfrontowej”; zagrożenie i osamotnienie w pełnionej misji awangardy rewolucyjnej; silne poczucie dyscypliny partyjnej. A w przypadku wielu działaczy, dla których ważne były idee rewolucji i którzy w pewnym momencie znaleźli się w konflikcie z suwerenem zewnętrznym, ważna była obawa, aby nie znaleźć się poza korpusem walczących ${ }^{7}$. Niewątpliwie wszystkie te cechy można odnaleźć w postawach polskich komunistów. W okresie międzywojennym nie było miejsca, gdzie mogli czuć się bezpiecznie: byli inwigilowani zarówno w Polsce, jak i za granicą.

Wydaje się, że syndrom „oblężonej twierdzy” należy połączyć ze specyfiką partii komunistycznych w pierwszym okresie jej rozwoju, kiedy występowała, jak to określił Maurice Duverger, w charakterze ,partii-zakonu”. Partia taka łączyła swych członków szczególnym rodzajem spoiwa, opierała się na silnej więzi o charakterze poświęcenia, wymagającej zaangażowania całej osobowości człowieka, na przekonaniu o zagrożeniu i osamotnieniu w pełnionej misji awangardy rewolucyjnej, potrzebie wierności etosowi rewolucyjnemu, absolutnej dyscypliny i podporządkowania zgodnego ze ściśle hierarchiczną strukturą ${ }^{8}$.

Elementy syndromu oblężonej twierdzy można znaleźć w działaniach komunistów w okresie Polski Ludowej, zwłaszcza do 1956 roku. Co prawda partia komunistyczna działała legalnie i korzystała z całego aparatu państwa ale nieustannie toczyła walkę. Wrogowie znajdowali się wszędzie: w redakcjach, gdzie prowadzili wrogą propagandę, w środowisku socjalistów, w „transmisjach masowych” (związkach zawodowych), aparacie bezpieczeństwa, aparacie państwowym i partyjnym ${ }^{9}$. Przekonanie o zmianie form działania wroga na bardziej podstępne, a przez to wyjątkowo groźne towarzyszyło naradom organizowanym przez resort. Nowe formy walki wroga miały polegać na przeniknięciu do różnych grup społecznych i opanowywaniu kluczowych stanowisk w aparacie władzy, w zakładach pracy, szkołach, partiach politycznych, organizacjach społecznych i zawodowych ${ }^{10}$. Rafał Stobiecki, znawca bolszewickiej filozofii dziejów, zauważył, że o ile w okresie leninowskim „wróg był przede wszystkim rywalem w walce o władzę” a jego działalność „dotyczyła głównie sfery politycznej” o tyle później „Metafora wroga rozprzestrzenia się na wszystkie dziedziny życia - politykę, gospodarkę, kulturę, szeroko rozumianą codzienność obywateli" ${ }^{11}$. Zmiana wyobrażeń o realnych bądź tylko potencjalnych zagrożeniach

7 P. Samuś, Syndrom „oblężonej twierdzy” w Komunistycznej Partii Polski [w:] Między Wschodem a Zachodem. Studia z dziejów polskiego ruchu i myśli socjalistycznej, red. A. F. Grabski, P. Samuś, Łódź 1995, s. 183 i n.

8 K. Sobolewska-Myślik, Partie i systemy partyjne na świecie, Warszawa 2004, s. 59.

9 Zob. dyskusję nad referatem B. Bieruta Zadania Partii w walce o czujność rewolucyjna na tle sytuacji obecnej [w:] III Plenum Komitetu Centralnego Polskiej Zjednoczonej Partii Robotniczej (11, 12, 13 listopada 1949 r.), „Nowe Drogi” 1949 [numer specjalny], s. 74, 89, 96, 123, 159, 165-166, 169, 188.

${ }^{10}$ Materiaty odprawy kierowników i zastępców kierowników WUBP oraz przedstawicieli wydziałów $V w$ dniu 28 marca 1948 r. [Julia Brystygierowa] [w:] Aparat bezpieczeństwa w latach 1944-1956: taktyka, strategia, metody, cz. 2: Lata 1948-1949, oprac. A. Paczkowski, Warszawa 1994, s. 32-33.

${ }^{11}$ R. Stobiecki, Bolszewizm a historia. Próba rekonstrukcji bolszewickiej filozofii dziejów, Łódź 1998, s. 155. 
powodowała, że wrogiem mógł zostać każdy, bez względu na status, czy wykonywany zawód. Pewne za to było, że wróg działał w sposób niejawny i przez to był szczególnie niebezpieczny.

Niewątpliwie komunistów charakteryzowała nadmierna podejrzliwość w stosunku zarówno do otoczenia, jak i współtowarzyszy. Dostrzegano potrzebę walki z prowokacją. Każda ekipa kierownicza była wyczulona na krytykę ze strony suwerena zewnętrznego za dopuszczenie do „zaśmiecenia” partii wrogami klasowymi, a jej następcy za nieprzezwyciężenie tego stanu rzeczy. To agenci mieli doprowadzić do walk frakcyjnych w KPP, i ukazywania partii jako ,obcej polskiemu narodowi, obojętnie odnoszącej się do narodowych odczuć polskich robotników i chłopów"12. W dwie dekady później, już w Polsce Ludowej, Stefan Kalinowski, prokurator generalny, w czasie jednej z dyskusji w 1953 r. za groźne uznał nawet łamanie czy choćby tylko naruszenie prawa, gdyż powodowało „wyłom, przez który wciska się wróg"13. Adam Humer, szczególnie okrutny funkcjonariusz MBP, tłumaczył wówczas, że nie chodziło o to, aby „,nie bić aresztowanego”, ale o „,bezradność i bezczynność wobec licznych bezkarnie uchodzących nieprawości"14, co miało był błędem.

„Pożeraniu własnych dzieci” służyło zapotrzebowanie na wroga, który pozwalał realizować różne cele wewnątrz i na zewnątrz partii. Carl Schmitt, sprowadzając istotę polityki do permanentnej rozprawy z przeciwnikiem, poczynił ważne ustalenie: chodziło tak o eliminację „złych ludzi”, jak i o większe przedsięwzięcie - o likwidację wrogiej struktury politycznej ${ }^{15}$. Zatem partia polityczna, aby była skuteczna, musiała uwzględniać konieczność walki z wrogimi: po pierwsze, z konkurencyjnymi i występującymi równolegle podmiotami polityki oraz po drugie, oceniając rzeczywistość, rozpoznać zjawiska i momenty zagrażające tożsamości i istnieniu danego podmiotu ${ }^{16}$. W tym drugim przypadku chodziło o wroga symbolicznego (przedmiotowego), jakim były w pierwszym rzędzie różnego rodzaju „herezje”, czyli odstępstwa od ortodoksji marksistowsko-leninowskiej i wspierający je ludzie.

\section{PRZYKŁADY „POŻERANIA WLASNYCH DZIECI”}

Poszukiwanie wrogów we własnych szeregach było pochodną różnych czynników. Podstawowym czynnikiem, charakterystycznym dla lat 20 . i 30 . było nasilenie procesu totalizacji ZSRR i WKP (b), który dotknął też MK i inne partie komunistyczne. W miarę upływu czasu wpływ MK, a de facto władz ZSRR na poszczególne sekcje zwiększył się.

12 Cyt. za: H. Cimek, Komuniści. Polska. Stalin 1918-1939, Białystok 1990, s. 100.

${ }^{13}$ Odprawa krajowa MBP z dnia 7 lipca [1953 r.] [w:] Aparat bezpieczeństwa w Polsce w latach 1953-1954. Taktyka, strategia, metody, wstęp A. Paczkowski, wybór i oprac. G. Majchrzak, A. Paczkowski, Warszawa 2004, s. 169.

${ }^{14}$ Stenogram dyskusji na naradzie krajowej aktywu kierowniczego aparatu bezpieczeństwa publicznego 4 marca 1954 r...., 317.

15 Zob. F. Ryszka, Poglądy na koncepcje państwa, „Studia Nauk Politycznych” 1984, nr 5, s. 21.

${ }^{16}$ R. Skarzyński, Wróg i sojusznik. Studium struktury myśli politycznej, „Studia Nauk Politycznych” 1990, nr 1-3, s. 59-88; R. Skarzyński, Historia myśli politycznej w ujęciu politologicznym. Zarys koncepcji, „Studia Polityczne” 1992, nr 1, s. 107-119; R. Skarzyński, Intelektualiści a ideologia. Myśl polityczna jako przedmiot badań politologa, „Studia Nauk Politycznych” 1990, nr 4-6, 7-32. 
W okresie Polski Ludowej, oprócz - zdaniem rządzących - nieustannie wrogiego otoczenia zewnętrznego w postaci państw kapitalistycznych, dodatkowym ważnym czynnikiem było niezadowolenie i rozczarowanie społeczne w kolejnych latach budowy socjalizmu, wyrażające się jawnym buntem. Po stronie władzy zjawisko to rodziło wielokrotnie potrzebę znalezienia „kozła ofiarnego”, na którego można było zrzucić odpowiedzialności za różnorodne nieprawości i niepowodzenia. Dla lat 60 . XX wieku doszły jeszcze wydarzenia zewnętrzne. Jednym z nich była wojna izraelsko-arabska, w której kraje komunistyczne jednoznacznie poparły państwa arabskie. Stało się to wtedy, gdy nie ziścił się projekt ZSRR utworzenia na Bliskim Wschodzie komunistycznego państwa żydowskiego. Polacy sympatyzowali wówczas z Izraelem. W sposób naturalny syjonizm będący podbudową teoretyczną dla zwolenników państwa żydowskiego na Bliskim Wschodzie stał się dla komunistów wrogą ideologią. Innym ważnym wydarzeniem była praska wiosna, czyli podjęta przez liberalną część Komunistycznej Partii Czechosłowacji reforma systemu politycznego. W Czechosłowacji domagano się ,,socjalizmu z ludzką twarzą”. Zmiany tam zapoczątkowane wywołały zaniepokojenie innych przywódców bloku i obawy o to, że postulaty reform „,rozleją” się na inne państwa komunistyczne. Z punktu widzenia interesów rządzących potrzebny był nowy wróg, aby rozładować napięcie społeczne.

„Pożeraniu własnych dzieci” służyła walka z herezją. Na użytek walki wewnątrzpartyjnej uknuto oskarżenia o poglądy ,prawicowo-nacjonalistyczne”, „nacjonaloportunistyczne”, czy „oportunistyczne”, luksemburgizm, trockizm, rewizjonizm, syjonizm czy dogmatyzm ${ }^{17}$. Były to terminy o wydźwięku pejoratywnym. Oskarżenie o odchylenie prawicowo-nacjonalistyczne pojawiło się po raz pierwszy w 1925 roku w odniesieniu do przywódców z pierwszych lat istnienia KPP (tzw. grupy „3W”) a w 1929 roku objęło całą grupę starszego pokolenia działaczy, liderów Polskiej Partii Socjalistycznej-Lewicy i Socjaldemokracji Królestwa Polskiego i Litwy, niewątpliwie bardziej samodzielnych w myśleniu, niejako „wyrosłych” w atmosferze dyskusji i sporów intelektualnych. Generalnie odnosiło się do poglądów, które przynajmniej w jakiejś mierze uwzględniały specyfikę polską. Kampania walki z ,prawicowcami” w KPP miała związek z przygotowaniem przez Stalina planu usunięcia ze sceny politycznej Nikołaja Bucharina, współtwórcy NEP, co stało się w kwietniu 1929 roku, i przejścia do kolejnego etapu budowy komunizmu w ZSRR. Niewątpliwie miały związek z walką frakcyjna w WKP (b), a co za tym idzie w MK i KPP.

Komuniści akceptowali stalinowską tezę, wysuniętą pod koniec lat 20. o zaostrzaniu się walki klasowej w miarę postępów budownictwa socjalistycznego oraz o „wrogach ludu” z lat późniejszych ${ }^{18}$. Walka o „czystość” ideologiczną, spleciona zawsze z walką o władzę w partiach komunistycznych była ważną częścią poczynań komunistów. Przejawiało się to najpierw atakiem na tzw. prawicę (w 1923 r. grupę ,3W”), następnie na grupy lewackie i trockistów (Leon Domski i in.), później ponownie na „prawicę”, a na koniec resztę kierownictwa KPP, co ostatecznie zakończyło się likwidacją partii i straceniem jej przywódców i działaczy.

17 Zob. J.W. Stalin, O Komunistycznej Partii Polski. Przemówienie na posiedzeniu komisji polskiej Kominternu 3 lipca 1924 r. [w:] J.W. Stalin, Dzieta, t. 6, Warszawa 1951, s. 267, 269, 273-274; M. Popow, Idealizacja luksemburgizmu - sztandar naszych wrogów, „Orka”, 27 grudnia 1931; J. Ryng, Luxemburgizm w kwestii polskiej [w:] J. Ryng, Wybór pism, Warszawa 1957, s. 391-496; W. Gomułka, Przemówienia. Październik 1956-wrzesień 1957, Warszawa 1959, s. 328.

${ }^{18}$ O brakach w pracy partyjnej i środkach zlikwidowania trockistów i innych dwulicowców [referat J. Stalina na Plenum KC WKP(b) 3 III 1937], „Przegląd”, kwiecień 1937 [dodatek]. 
Fizyczna likwidacja przywódców KPP przez NKWD, dokonała się w latach 1936-1938. Komuniści przebywający w Moskwie byli aresztowani i rozstrzeliwani, inni, przebywający poza granicami ZSRR wzywani do przyjazdu i także straceni. Na 100 osób będących członkami i zastępcami członków KC represjom poddano 69 proc. Przeżyli ci, co pozostawali w polskich więzieniach, bądź byli w krajach Europy Zachodniej. Nikt nie został skazany przez sąd.

Rozprawa Stalina z KPP była konsekwencją i organicznym produktem modelu partii i państwa totalitarnego zbudowanego w ZSRR. Ten model mógł funkcjonować m. in. przy założeniu istnienia wroga wewnętrznego i zewnętrznego, który uzasadniał potrzebę stosowania nadzwyczajnych środków do represjonowania ludzi, ich mobilizacji, czy konieczność różnorodnych wyrzeczeń. Ujawnienie licznych wrogów pozwalało wytłumaczyć dlaczego, mimo wielkich wyrzeczeń, ciągle kraj był biedny, a ludziom żyło się nie najlepiej. To niejako kolejny etap przemian, w którym rewolucja ,pożarła swoje dzieci”19.

KPP została zlikwidowana w ramach „operacji polskiej” rozpoczętej w sierpniu 1937 roku, prowadzonej równolegle z „operacjami” niemiecką, bułgarską, grecką, fińską, estońską, koreańską itp. Aresztowani zostali wszyscy pozostali przy życiu jeńcy z wojny polskoradzieckiej, wszyscy uchodźcy i imigranci do ZSRR, wszyscy członkowie polskich partii politycznych oraz działacze z polskojęzycznych obszarów ZSRR, osoby polskiego pochodzenia mieszkający zwłaszcza na Ukrainie i Białorusi radzieckiej. W sumie aresztowano ponad 140 tys. osób, co badacze szacują na 10\% wszystkich ofiar Wielkiej Czystki. KPP spośród partii, wobec których zastosowano terror, poniosła największe straty. Polscy komuniści pod względem zastosowanych wobec nich represji zajęli drugie miejsce (po Rosjanach $)^{20}$.

Odchylenie prawicowo-nacjonalistyczne ponownie odkryto i napiętnowano w latach 40. i w pierwszej połowie lat 50. Nie wnikając w genezę odchylenia prawicowo-nacjonalistycznego, bo była różnie tłumaczona w literaturze przedmiotu, niewątpliwie odzwierciedlała trendy typowe ZRSR i WKP(b). Chodziło przede wszystkim o walkę o władzę wewnątrz partii komunistycznych, podczas której odwoływano się do suwerena zewnętrznego. Sukces w partii dawał władzę nad państwem.

Gomułkowszczyzna - łączna nazwa kwestionowanych poglądów, była jeszcze jedną w ruchu komunistycznym herezją. Kampania walki z „,prawicowcami”, tak jak w okresie międzywojennym miała związek z przygotowaniem przez Stalina planu zmiany taktyki: tym razem przyspieszenia sowietyzacji Europy Środkowo-Wschodniej. Towarzyszyła temu wymiana kadr, czyli odsunięcie od władzy ludzi kojarzonych z realizacją poprzedniego etapu na rzecz komunistów, którzy stanowisko zawdzięczali bezpośrednio przywódcy ZSRR. Pierwszym „kozłem ofiarnym” stał się Josip Broz Tito, przywódca komunistów w Jugosławii i, jak trafnie zauważył Andrzej Paczkowski, przejął obowiązki ,nowego Troc-

${ }^{19}$ Roman Werfel, działacz komunistyczny, oceniający Stalina jako połączenie ,prymitywizmu, nieznajomości świata oraz geniuszu”, a starych bolszewików jako ludzi szlachetnych zbrodnie tłumaczył tym, że Stalin dla zwycięstwa swej koncepcji ,musiał zlikwidować całe pokolenie, które pamiętało, że mogło być inaczej”. Zob. T. Torańska, Oni..., s. 289.

${ }^{20} \mathrm{O}$ represjach wobec KPP zob. szerzej: K. Trembicka, Między utopia a rzeczywistością. Myśl polityczna Komunistycznej Partii Polski (1918-1938), Lublin 2007, s. 270 i n.; . N. Pietrow, A. Roginskij, Polska operacja NKWD. 1937-1938 [w:] Riepriesii protiw Polakow i polskich grażdan, Moskwa 1997, s. 33; N. Pietrow, Polska operacja NKWD, „Karta” 1993, nr 11, s. 24 i n. 
kiego" 21 . Można sądzić, że w ówczesnej sytuacji jeżeli nie byłoby Tito, to do tej roli znalazłby się ktoś inny ${ }^{22}$.

Odchylenie prawicowo-nacjonalistyczne zostało ujawnione w czasie plenum sierpniowo-wrześniowego w 1948 r. Z przywódców Polskiej Partii Robotniczej (poprzedniczki PZPR), a co za tym idzie i państwa pod ostrzałem znaleźli się Władysław Gomułka i jego otoczenie: Zenon Kliszko, Władysław Bieńkowski, Ignacy Loga-Sowiński, Grzegorz Korczyński, Mieczysław Moczar. Analogiczne procesy zachodziły w innych państwach „,demokracji ludowej”. „Odchylenie”, zlokalizowane na poziomie centrum, a także odkrywane stopniowo w lokalnych instancjach partyjnych, miało być zbiorem odbiegających od linii kierownictwa partii poglądów. Dodatkowo Gomułka miał być bezpośrednio odpowiedzialny za ,ślepotę” i brak czujności, co doprowadziło do przeniknięcia wrogów do aparatu państwowego oraz brak zrozumienia związku między ,zdradzieckimi teoriami kliki titowskiej" a nacjonalistycznym odchyleniem, które prezentował ${ }^{23}$.

Wymienione zarzuty były jedynie pretekstem do odsunięcia Gomułki od władzy. Jak stwierdzono wyżej, Gomułka i tak musiał stracić stanowisko, gdyż poddał w wątpliwość słuszność postępowania Stalina w sporze z Tito oraz potrzebę istnienia Biura Informacyjnego Partii Komunistycznych i Robotniczych.

Preludium do oficjalnej rozprawy z gomułkowszczyzną był artykuł Edwarda Ochaba w „Nowych Drogach”, organie teoretycznym partii, pt. Walka trwa, w którym autor zarzucił „,zniekształcenie nauki Lenina”"24. Ostateczną rozprawę z „odchyleniem” jako wewnętrznym wrogiem ideologicznym podjęto w czasie III Plenum KC PZPR (11-13 listopada 1949 r.). Decyzje personalne zapadły wcześniej ${ }^{25}$, niemniej oficjalnie na III Plenum KC PZPR pozbawiono Gomułkę i kilku innych polityków członkostwa w gremium kierowniczym partii.

W następstwie walki z gomułkowszczyzną nastąpiła eliminacja dwóch grup działaczy: 1) tzw. krajowców, czyli komunistów, którzy spędzili wojnę w okupowanej Polsce, na rzecz komunistów przybyłych wraz z Armią Czerwoną z ZSRR. Formalnym liderem tej grupy był Bolesław Bierut, wspierany przez Jakuba Bermana, Hilarego Minca, Romana

${ }^{21}$ Lew Trocki był jednym z przywódców rewolucji październikowej i partii bolszewickiej na początku lat 20. a po śmierci Lenina konkurentem Stalina do najwyższej funkcji w państwie. Stał się pierwszym kozłem ofiarnym i wrogiem wewnętrznym, którego koncepcje polityczne, potraktowane jak herezja zostały potępione. Trocki, po pozbawieniu wszystkich funkcji najpierw został w 1929 r. wydalony ze ZSRR, a następnie, gdy przebywał na emigracji w Meksyku, w 1940 zamordowany przez radzieckie służby specjalne.

${ }^{22}$ Aparat bezpieczeństwa w latach 1944-1956: taktyka, strategia, metody, cz. 2: Lata 1948-1949, oprac. A. Paczkowski, Warszawa 1994, s. 7.

${ }^{23}$ Zob. wystąpienie Jerzego Albrechta, Hilarego Minca, Romana Werfla, Aleksandra Zawadzkiego, Jana Ptasińskiego i Stefana Staszewskiego w dyskusji nad referatem B. Bieruta Zadania Partii $w$ walce o czujność rewolucyjna na tle sytuacji obecnej w czasie III Plenum Komitetu Centralnego Polskiej Zjednoczonej Partii Robotniczej 11 listopada 1949 r.), „Nowe Drogi” 1949, s. 67, 85, 90, $118,141-142,145,154$.

${ }^{24}$ E. Ochab, Walka trwa, „Nowe Drogi” 1949, nr 5, s. 28.

25 Wniosek o ,wyprowadzenie ze składu KC" Gomułki, Spychalskiego i Kliszki zgłosił Bierut 10 listopada 1949 r. jako konkluzję do referatu o potrzebie „czujności rewolucyjnej” na III Plenum. Zob. Protokót z posiedzenia Biura Politycznego KC PZPR z dnia 10 listopada 1949 r. [w:] Dokumenty do dziejów PRL. Centrum wtadzy. Protokoły posiedzeń kierownictwa PZPR. Wybór z lat 1949-1970, oprac. A. Dudek, A. Kochański, K. Persak, Warszawa 2000, s. 32. 
Zambrowskiego; 2) wszystkich, którzy nie zaakceptowali realizowanej przez PPR/PZPR formuły unifikacji życia politycznego, a byli związani z partiami historycznymi - PPS i PSL. Oprócz partii czystki objęły wojsko i służbę bezpieczeństwa.

Oskarżeni o odchylenie prawicowo-nacjonalistyczne spotkali się z represjami. W Polsce aresztowania objęły około 750 osób. Spośród ludzi ulokowanych wysoko w aparacie władzy aresztowano wojskowych i funkcjonariuszy partyjnych. W latach 1951-1954 aresztowano i skazano 83 oficerów. Aresztowani oficerowie traktowani byli jak wrogowie narodu, faszyści i ,lokaje” imperializmu ${ }^{26}$.

Ostatecznie Gomułka nie stracił życia, do procesu nie doszło, nie było także pokazowego procesu członków partii. Można przypuszczać, że wpływ na to miała pamięć o doświadczeniu KPP i obawa nowego kierownictwa o to, że po Gomułce mogą być następni w kolejności do aresztowania i procesu. Gomułka życie zawdzięczać mógł własnej determinacji w śledztwie. Wolność osobistą uzyskał w grudniu 1954 r., aż półtora roku po śmierci Stalina. Dopiero zmiana na Kremlu i wycofanie przez Chruszczowa zarzutu o agenturalności Tito wpłynęły na zmianę stosunku do Gomułki, część zarzutów okazała się nieprzydatna $^{27}$.

„Odwilż” w 1956 roku przyniosła niewielką rewolucję personalną. Przełom październikowy pozwolił na zachowanie ciągłości. Zmiany personalne nie naruszyły trzonu elity władzy. Pozostała niemal w całości kadra średniego i niskiego szczebla. Zmiany personalne objęły kilka tysięcy pracowników aparatu partyjnego ${ }^{28}$. Dotychczasowi przywódcy: Berman, Minc, Zambrowski, wysokiej rangi funkcjonariusze państwowi i partyjni ${ }^{29}$, winni nadużyć w resorcie bezpieczeństwa stali się w połowie lat 50. wygodnym kozłem ofiarnym. Nieliczne wyroki skazujące miały pokazać społeczeństwu determinację, wolę i przede wszystkim praworządność sprawujących władzę. Była to swoista „ucieczka do przodu”. Pokazanie winnych, Żydów i funkcjonariuszy UB miało odwrócić uwagę społeczeństwa od innych współtwórców totalitaryzmu w Polsce. Przykład szedł z Moskwy, gdzie Beria, szef NKWD, był tym stalinowcem, który zainicjował liberalizację systemu i ostatecznie stracił życie.

Zmiany w gremiach kierowniczych PZPR, jakie dokonały się później, były pochodną walki z kolejną herezją a nie skutkiem oceny postaw w okresie stalinowskim. Typowe, wzorem zjawisk występujących wcześniej w KPP i w innych partiach komunistycznych, było dostrzeżenie zagrożenia we wszystkim, co nie było zgodne z oficjalną wykładnią doktryny, a nie mieściło się w znanej i realizowanej wersji komunizmu. Stąd kolejna ekipa, z przywróconym do władzy Gomułką, dostrzegła zagrożenie w rewizjonistach, partyjnych

${ }^{26}$ L. Pawlikowski, Tajny front zimnej wojny. Uciekinierzy z polskich służb specjalnych 1956-1964, Warszawa 2004, s. 50-51; J. Poksiński, ,,TUN” Tatar-Utnik-Nowicki. Represje wobec oficerów Wojska Polskiego w latach 1949-1956, Warszawa 1992 (rozdział II); W. Ważniewski, Walka polityczna w kierownictwie PPR i PZPR 1944-1964, Torun 1991, s. 44-45.

${ }^{27}$ Szerzej zob. K. Trembicka, Wrogowie i przeciwnicy. Studium myśli politycznej Polskiej Zjednoczonej Partii Robotniczej, Lublin 2013, s. 229 i n.

${ }^{28}$ Do końca marca 1957 r. zwolniono ze stanowisk kierowniczych 33 członków i zastępców członków KC, 51 sekretarzy KW, 35 ministrów i wiceministrów; do połowy 1957 r. zwolniono przeszło 8, 6 tys. osób z aparatu partyjnego. Zob. W. Ważniewski, Walka polityczna w kierownictwie PPR i PZPR 1944-1964..., s. 106-107.

29 A. Paczkowski, Aparat bezpieczeństwa w latach odwilży: casus polski, „Zeszyty Historyczne” 1995, z. 114, s. 3-33. 
reformatorach. Nowa ekipa obawiała się wszystkiego, co nie podlegało kontroli ze strony centralnego aparatu władzy.

O potrzebie wykreowania nowego wroga w postaci rewizjonistów, syjonistów i kosmopolitów ponownie rozstrzygnął suweren zewnętrzny. Stwierdzić należy, że przed pojawieniem się rewizjonistów, mimo rewelacji XX Zjazdu KPZR, nie było wypowiedzi oceniających marksizm jako ideologię skompromitowaną, a zbudowany na niej model ustrojowy jako nienaprawialny ${ }^{30}$.

Walka z rewizjonizmem trwała niemal dekadę lecz jej szczególne nasilenie przypadło na początek i schyłek rządów Gomułki. Początek ofensywy nastąpił w listopadzie 1956 r. na łamach „Trybuny Ludu”, gdzie w artykule wstępnym od redakcji zakwestionowano utożsamianie istoty socjalizmu z jego ,wypaczeniami” oraz żądano, aby ludzi odpowiedzialnych za politykę poprzedniego okresu wyeliminować z czynnego życia politycznego ${ }^{31}$.

Rewizjonistami nazwano część elity władzy, która swoją aktywność zintensyfikowała w związku z wydarzeniami 1956 r. i rozbudzonymi wówczas nadziejami na zmiany we wszystkich dziedzinach. Jak pisał Andrzej Friszke, historyk i badacz tej problematyki, popaździernikowi „buntownicy” wyciągnęli wnioski z krytyki stalinizmu i domagali się głębokiej przebudowy ustroju, aby zbliżyć się do ,pierwotnego socjalizmu”, odwoływali się do marksizmu. Dla rewizjonistów stalinizm nie był błędem, lecz totalnym systemem politycznym ${ }^{32}$.

Dla komunistów rewizjonizm był zagrożeniem większym niż dostrzeżony w tym samym czasie dogmatyzm. Konflikt z osobami postulującymi zmianę stanowiska w kwestii tego, co stanowiło instytucjonalne sedno systemu politycznego był nieunikniony. Uznanie twierdzeń głoszonych przez rewizjonistów byłoby równoznaczne z zanegowaniem podstawowych zasad ideologii, na której bazowała partia oraz tego wszystkiego, co zbudowano w ZSRR.

Kampanię przeciwko rewizjonizmowi Gomułka rozpoczął na X Plenum KC PZPR w 1957 r. Był to element walki o unifikację wartości w sferze publicznej i niejako o „rząd dusz", niezbędnych w działaniach na rzecz stworzenia pożądanego modelu społeczeństwa. Jak się wydaje, w ówczesnej sytuacji istota sporu dotyczyła kwestii podstawowej, modelu partii - czy PZPR miała być jak dotąd partią komunistyczną czy też socjaldemokratyczną, dopuszczającą swobodę dyskusji i demokrację wewnętrzną, istnienie niezależnych od władz organizacji, samorząd robotniczy czy niezależne związki zawodowe, co niewątpliwie w zasadniczy sposób zmieniłoby system polityczny PRL. Dla rządzących komunistów postulowana przez rewizjonistów de facto demokracja parlamentarna była niemożliwa do zaakceptowania.

X Plenum KC PZPR zakończyło okres tolerancji wewnątrzpartyjnej. Likwidacja „rewizjonistycznego czadu" [określenie W. Gomułki - przyp. K.T.] ${ }^{33}$ oznaczała w pierwszym rzędzie weryfikację członkostwa w partii, ale także unifikację poglądów. Za rewizjonizm

\footnotetext{
${ }^{30}$ Zob. B. Fijałkowska, Gtos w dyskusji nt. „, Wydarzenia kryzysowe w Polsce w latach 1955-1957” (stenogram dyskusji redakcyjnej), „Z Pola Walki” 1982, nr 1-2, s. 112.

31 Dokad zmierza ta demagogia, „Trybuna Ludu”, 28 listopada 1956.

32 A. Friszke, Opozycja polityczna w PRL 1945-1980, Londyn 1994, s. 133 i n; Z. Romek, Droga Leszka Kołakowskiego ku antykomunistycznej opozycji. Od ortodoksyjnej ideologii ku wolności myślenia, „Dzieje Najnowsze” 1999, nr 4, s. 139-146.

33 Zob. W. Gomułka, Przemówienia. Wrzesień 1957-grudzień 1958..., s. 338.
} 
z PZPR usunięto w krótkim czasie prawie 800 osób ${ }^{34}$. Konsekwencje ponieść musieli dziennikarze czasopism wspierających „,odwilż” („Po Prostu”) i co bardziej znani działacze partyjni i społeczni (Jacek Kuroń i Karol Modzelewski) chcący przybliżenia Polski Ludowej do własnej, opartej na wzorcu marksistowskim wersji komunizmu.

Rozstrzygnięcie walki z rewizjonizmem nastąpiło w końcu lat 60. w sytuacji kryzysu politycznego i gospodarczego w Polsce, walki o władzę i wpływy wewnątrz PZPR, wiedzy rządzących o możliwości wybuchu niezadowolenia społecznego, zwłaszcza po przeprowadzonej jesienią 1967 r. podwyżce cen $^{35}$. Na sytuację w Polsce w tym czasie dodatkowo wpływ miały, sygnalizowane wcześniej, dwa wydarzenia zewnętrzne: kolejna wojna izraelsko-arabska oraz praska wiosna.

Przeciwko domniemanym wrogom socjalizmu ponownie wytoczono mocne argumenty. Obok rewizjonizmu równoległym zagrożeniem stał się syjonizm. Chociaż syjonizm jako „obca” ideologia nie był dla rządzących tak groźny jak rewizjonizm ze względu brak dostatecznie dużego zaplecza społecznego to, w konkretnej sytuacji, został potraktowany jako część kampanii przeciwko Polsce, organizowanej przez ośrodki zewnętrzne. Syjonizm stał się wrogą Polsce ideologią zawierającą w sobie negatywny obraz Polaków, w celu wytworzenia warunków do większej niż dotąd emigracji do Izraela ${ }^{36}$. Sympatie Polaków dla Izraela rządzącym pretekst do sformułowania zarzutów przeciwko niedookreślonym do końca syjonistom. Chodziło o osoby, które miały charakteryzować się postawą uległości wobec „kosmopolitycznego nihilizmu narodowego” i „,ciasnego nacjonalizmu”. Pożądane były patriotyzm i „moralność socjalistyczna" ${ }^{37}$. Kosmopolityzm był aluzją do pochodzenia żydowskiego, zarzutem wobec postawy jakoby wyszydzającej polskie tradycje patriotyczne, nadmierną usłużność wobec władz ZSRR. Stwierdzić trzeba, że walka z syjonizmem była częścią szerszego procesu i zjawiska, które można umieścić w ramach Marca 1968. Marzec ' 68 toczył się na kilku planach jednocześnie: łączył w sobie m.in. protest studencki i walkę wewnątrz PZPR z odwołaniem się do antysemityzmu ${ }^{38}$.

Skutkiem walki z syjonizmem były zmiany kadrowe w partii i różnych instytucjach. Syjonizm był wygodnym pretekstem, pod którym można było ukryć prymitywny antysemityzm i pozbyć się części kadry pochodzenia żydowskiego. Antysemityzm był wypróbowanym ,argumentem” uzasadniającym zmiany kadrowe i choć sprzeczny z internacjonalizmem, był obecny w ruchu komunistycznym. Charakteryzował chociażby politykę personalną ZSRR i niektórych innych państw komunistycznych.

Stwierdzić trzeba, że usuwanie z różnych instytucji politycznych obywateli polskich pochodzenia żydowskiego trwało już od kilku lat. W MSW postępowało od 1964 r. a miało związek z powołaniem Mieczysława Moczara na urząd ministra spraw wewnętrznych.

${ }^{34}$ Zob. B. Dymek, Z dziejów PZPR w latach 1956-1970..., s. 176.

35 Zob. J. Eisler, Cykliczne kryzysy władzy -źródta i konsekwencje, ,Wiadomości Historyczne” 2000, nr 1, s. 1-8.

${ }^{36}$ Przemówienie W. Gomułki w czasie XII Plenum KC PZPR [8-9 lipca 1968 r.], ,Nowe Drogi” 1968, nr 8, s. 133.

37 Wystapienie Z. Kliszko w czasie XII Plenum KC PZPR, „Nowe Drogi” 1968, nr 8, s. 17, 19; Sprawozdanie $K C$ oraz Zadania partii w dziedzinie umacniania socjalizmu i dalszego rozwoju PRL. Referat I sekretarza KC PZPR tow. Wtadystawa Gomutki, „Nowe Drogi” 1968, nr 12, s. 39.

38 A. Friszke, Miejsce Marca 1968 wśród innych „polskich miesięcy” [w:] Oblicza Marca 1968, red. K. Rokicki, S. Stępień, Warszawa 2004, s. 15. 
Podobne procesy zachodziły w wojsku. Ewidencja obywateli według kryterium narodowościowego, jako punkt wyjścia do walki z syjonizmem postępowała od lata $1967 \mathrm{r} .{ }^{39}$.

W latach 1968-1969 zmiany kadrowe dotknęły pracowników różnych instytucji. Ze stanowiskami pożegnali się obywatele polscy pochodzenia żydowskiego. Opuszczający kraj pozostawili po sobie posady na uczelniach, w MON, MSZ, aparacie partyjnym ${ }^{40}$. Z wysokich kręgów władzy odeszli: Edward Ochab, Adam Rapacki, Eugeniusz Szyr. Beneficjentami wymuszonej emigracji byli konkretni ludzie, którzy mogli osiągnąć drobne korzyści materialne: objęcie porzuconych stanowisk, kupno od emigrantów mebli, zajęcie zwolnionych lokali mieszkalnych.

PZPR, zanim została rozwiązana w 1990 roku, stoczyła jeszcze wiele wojen. W latach 60. problemem był dogmatyzm, cecha charakterystyczna komunistycznego stylu myślenia, obecna i w okresie międzywojennym. W 1964 roku dogmatykami byli zwolennicy poglądów Mao Tse-tunga oraz grupa tzw. lewicy patriotycznej, pogrobowców moczarowców. W latach 1980-1981 r. pojawiło się zagrożenia w postaci powstałych w Toruniu ,struktur poziomych", definiowanych jako narzędzie rozbijania partii od wewnątrz ${ }^{41}$. Ich początek dało porozumienie organizacji partyjnych kilku zakładów pracy i uniwersytetu. Inicjatywa znalazła naśladowców w kilku innych miastach ${ }^{42}$.

Próbą przeciwdziałania deformacjom, jakie trapiły partię w okresie stanu wojennego była ostatnia „,czystka”, przeprowadzona w 1982 r., kiedy usunięto z jednej strony, ludzi „chwiejnych i obcych ideowo”, a z drugiej strony wyeliminowano polityków znajdujących się w dwóch różnych skrzydłach partii: tzw. dogmatyków oraz liberałów zgrupowanych wokół czasopism krytykujących realizowaną politykę - „Rzeczywistość” oraz „Zdanie”43.

Stwierdzić należy, że dokonywane represje nie wywoływały negatywnego oddźwięku w partiach. Komuniści polscy identyfikowali się z komunistami radzieckimi. W partiach komunistycznych, za wyjątkiem jednostek, nie było działaczy, którzy podjęliby polemikę z przywódcami z RKP(b)/KPZR. Spośród przywódców KPP jedynie Maria Koszutska zwróciła uwagę na niewłaściwe relacje między MK a poszczególnymi jej sekcjami, ograniczanie swobody dyskusji, formy rozwiązywania konfliktów wewnątrzpartyjnych. Była po Róży Luksemburg a w KPP jedyną ważną postacią, która w sposób otwarty zastanawiała się nad modelem partii robotniczej. Koszutska właściwie uchwyciła początek procesu negatywnych zmian w RKP(b), MK, a także - co pokazała nieodległa przeszłość - w poszczególnych sekcjach, czyli nadmierną centralizację, metody podejmowania decyzji w wąskim gronie, rozstrzyganie spornych kwestii poprzez eliminowanie z kierownictwa inaczej myślących, zjawisko oskarżania o oportunizm bardziej realistycznie myślących komunistów ${ }^{44}$.

${ }^{39}$ P. Wieczorkiewicz, Walka o władze w kierownictwie PZPR w Marcu 1968, [w:] Marzec 1968. Trzydzieści lat później, t. 1, red. M. Kula, P. Osęka, M. Zaremba, Warszawa 1998, s. 45; K. Lesiakowski, Mieczystaw Moczar „Mietek”. Biografia polityczna, Warszawa 1998, s. 308.

${ }^{40}$ Szczegółowe dane zob. K. Lesiakowski, Emigracja osób pochodzenia żydowskiego z Polski w latach 1968-1969, „Dzieje Najnowsze” 1993, nr 2, s. 117.

${ }^{41}$ List Komitetu Centralnego KPZR do KC PZPR, [5 czerwca 1981 r.], ND 1981, nr 7, s. 30-31.

${ }^{42}$ E. Duraczyński, PZPR w kryzysie - kryzys w PZPR (lato 1980 - lato 1981), „Dzieje Najnowsze” 1997, nr 4, s. 80-81; R. Bäcker, Struktury poziome w Toruniu (1980-1981), Warszawa 1990, passim.

43 Szerzej zob. A. Dudek, Obóz władzy w okresie stanu wojennego, „Pamięć i Sprawiedliwość” 2002, nr 2, s. 238-239.

${ }^{44}$ Zob. list z Moskwy do KC KPRP z 1 lutego 1923 r., AAN, VI Oddz., KPP, mf 728/1. 
Za każdym razem poddani presji ze strony towarzyszy komuniści kajali się za nie popełnione błędy. Postawa taka była charakterystyczna dla działaczy, którzy - jak mogło się wydawać - nie należeli do ludzi słabego charakteru, gdyż wielokrotnie dawał dowody odwagi i potrafił bronić swoich racji (Edward Próchniak, Adolf Warski, Maria Koszutska). Presja psychiczna i atmosfera izolacji były tak silne, że zrezygnowali z obrony swoich poglądów ${ }^{45}$. Samokrytyka, nieodzowny element sakralizacji partii, nie wpłynęła w żaden sposób na zmianę stosunku gremiów kierowniczych partii do odsuniętych przywódców.

O ile w 1948 roku los Gomułki i jego najbliższych współpracowników i tak był przesądzony o tyle to co pozostało do zrobienia, to zmuszenie go do kompletnej kapitulacji, bo przywódca partii komunistycznej nie mógł „tak sobie odejść”, wcześniej musiał zrozumieć i naprawić błędy, które popełnił, a jeżeli tego nie chciał zrobić, to znaczyło, że stawał do walki z partią ${ }^{46}$. III Plenum KC PZPR przyniosło więc wiele wystąpień, w których zaatakowani wysocy rangą funkcjonariusze partyjni, pełniący u progu Polski Ludowej rolę przywódczą w państwie, kajali się, mając nadzieję, że uchronią siebie przed degradacją. O ile zrozumieć można wyznanie winy z powodu faktycznych pomyłek czy błędnych decyzji, o tyle kuriozalna była samokrytyka za błędy niepopełnione. Tego typu zachowanie charakteryzowało chociażby Mariana Spychalskiego, który kajał się za to, że nie zauważył u siebie odchylenia prawicowo-nacjonalistycznego ${ }^{47}$. Nieco łagodniej prostował swoje „niedoskonałości” Ignacy Loga-Sowiński. Uległ nawet Gomułka, zmuszony ostatecznie zauważyć, że „klika titowska” nie tyle popełniała błędy, jak sądził uprzednio, ile prowadziła „działalność agenturowo-dywersyjną" ${ }^{48}$. Komuniści polscy dostosowali się do trendów występujących w ZSRR. Większość mówców zapewniła o swojej lojalności i prześcigała się w podkreślaniu mądrości i przenikliwości Stalina oraz tego, jak bardzo była przewidująca i zbawienna dla ruchu komunistycznego inicjatywa WKP(b) w sprawie jugosłowiańskiej. III Plenum było dobrym przykładem na pokazanie, że w krótkim czasie dokonała się sakralizacja partii. Samokrytyka była tego dowodem.

Zarzuty były de facto mało istotne, bo oskarżenia w obu przypadkach dotknęły komunistów zasłużonych w budowie systemu totalitarnego: najpierw w ZSRR a później, ci co przeżyli, w Polsce. W Polsce uznany za czołowego reprezentanta odchylenia Gomułka różnił się od innych komunistów tylko tym, że może mając na uwadze nieodległe doświadczenia Polaków z okresu wojny, bardziej niż inni zwracał uwagę na potrzebę zachowania pozorów niepodległości Polski. Nie uważał także, aby od razu trzeba było dokonać kolektywizacji rolnictwa.

Komuniści nie zdobyli się na protest w związku z aresztowaniem współtowarzyszy, tak w latach 30. jak i 50. XX wieku. Poszczególne partie komunistyczne bez zastrzeżeń potępiały różnorodnych „wrogów” a większość zweryfikowanych gremiów kierowniczych

45 P. Samuś, Edward Próchniak, Warszawa 1983, s. 276-277; S.S. Nicieja, Julian Leszczyński-Leński, Warszawa 1979, s. 294.

46 Wystąpienie Aleksandra Zawadzkiego w dyskusji nad referatem B. Bieruta Zadania Partii w walce o czujność rewolucyjna..., s. 158.

47 „Wykazałem się brakiem czujności przede wszystkim w wojsku. Wyrządziłem szkodę Partii [dużą literą w tekście - przyp. K.T.] przez tolerowanie wrogów i ułatwienie im zajęcia poważnych stanowisk w naszym aparacie państwowym, ułatwienie im przeniknięcia do Partii”. III Plenum Komitetu Centralnego Polskiej Zjednoczonej Partii Robotniczej..., s. 59.

${ }^{48}$ Wystapienie Gomutki w dyskusji nad referatem B. Bieruta „Zadania Partii w walce o czujność rewolucyjna na tle sytuacji obecnej”..., s. 112. 
i działaczy partyjnych przyjęła i zaakceptowała decyzję WKP(b) dotyczącą aresztowania kolejnych grup działaczy. Wielu komunistów solidaryzowało się z poczynaniami NKWD i wyrażało dla nich uznanie. Liczni aresztowani oskarżali nie tylko działaczy z wrogich sobie frakcji, ale i bliskich kolegów. W drugiej połowie lat 30. ich postawa nie znajdowała usprawiedliwienia, gdyż dla walki z pokonanym już ,przeciwnikiem”, odsuniętymi od wpływu na bieg spraw partyjnych towarzyszami, tworzono sztuczną podbudowę teoretyczną; niektórzy samoistnie ,,pomagali” NKWD i skarżyli współtowarzyszy, po aresztowaniu obciążali siebie nawzajem. Zwłaszcza współpracujący z NKWD komuniści polscy musieli orientować się w metodach ,pracy” radzieckich organów bezpieczeństwa. Postawa taka była najprawdopodobniej efektem przeobrażeń, w wyniku których zmianie uległ nie tylko kształt organizacyjny KPP, ale także wykształciła się tzw. stalinowska osobowość 49 . Niewątpliwie osobowość taka mogła wyrazić się w pełni jedynie w partii. Przypadłość ta dotknęła tak KPP, jak i inne partie komunistyczne.

Represje partyjne i karne, jakich doświadczył Gomułka i inni, nie spotkały się ze sprzeciwem, milcząco, ale zostały zaakceptowane. Po 1948 r. członkowie partii całkowicie poparli kierownictwo i nową linię polityczną. W połowie 1948 r. Władysław Bieńkowski był jedynym, który wystąpił w obronie Gomułki. U schyłku lat 60. nikt z kierownictwa partyjnego nie zatrzymywał ,syjonistów” ani tysięcy obywateli polskich żydowskiego pochodzenia, którzy zostali zmuszeni do opuszczenia państwa.

\section{WNIOSKI}

Rozważania na temat zjawiska „pożerania własnych dzieci” w partiach komunistycznych działających w Polsce pozwalają na konstatację, że represje, które dotknęły ich przywódców i działaczy były częścią większej całości i odbiciem wielu nakładających się na siebie tendencji. Pierwsza, podstawowa odzwierciedlała typowy dla partii komunistycznych styl myślenia i działania, przejawiający się w braku zaufania, obsesji zdrady, szpiegomanii, i była częścią szerszego zjawiska wiążącego się z syndromem „oblężonej twierdzy” oraz totalizacja partii i państwa. Zdaniem Hanny Arendt, represje wobec elity władzy, traktować można jako wyraz swoistego egalitaryzmu, gdyż były dowodem, że w systemie totalitarnym nie było lepszych i gorszych, wszyscy byli jednakowo równi przed tyranem i wszyscy od niego jednakowo zależni ${ }^{50}$. Druga tendencja była pochodną podjętej przez suwerena zewnętrznego inicjatywy dokonania zmiany personalnej, np. przez eliminację komunistów nazbyt samodzielnych oraz wymiany kadry w związku z przejściem do kolejnych etapów budowy państwa totalitarnego. Trzecia odnosiła się do relacji wewnątrz partii, a mianowicie do walki o władzę i korzystania z okoliczności do pozbycia się konkurentów. Zwycięstwo w partii pozwalało na sprawowanie władzy w Polsce. Komunistyczny system nie wypracował żadnego instytucjonalnego mechanizmu, który umożliwiałby naturalną rotację kadr. Walkę z różnego rodzaju herezjami wykorzystywano do zmian personalnych. Oskarżenie o poglądy sprzeczne z aktualną linią polityczną było wygodnym pretekstem do pozbycia się konkurentów politycznych. W partiach komunistycznych toczyła się brutalna

49 Owa stalinowska osobowość łączyła w sobie cechy „potentata, inkwizytora i prokuratora”. Przy zaistnieniu określonych warunków i okoliczności zawsze znajdowali się ludzie szczególnie predysponowani do odgrywania ,,jezuicko-dyscyplinarnej roli aparatczyka”, spragnieni składania donosów, oskarżeń i drwin. Zob. E. Morin, O naturze Związu Radzieckiego, Warszawa 1990, s. 55.

${ }^{50}$ Zob. F. Ryszka, Poglądy na koncepcję państwa..., s. 22. 
walka o władzę, włącznie z wykorzystywaniem NKWD a w Polsce Ludowej policji politycznej. Ewentualne zwycięstwo w partii dawało nadzieję na sprawowanie władzy w Polsce. Ważną zmianę w odniesieniu do polityki kadrowej przyniósł XX Zjazd KPZR: ograniczenie represji w stosunku do elity władzy. Po $1956 \mathrm{r}$. elita władzy uzyskała bezpieczeństwo osobiste. Zmiana była trwała, gdyż gwarantowano na ogół bezkarność i ochronę ustępującym sekretarzom. Z najwyższych rangą polityków z szykanami spotkał się Edward Gierek. Gierek oraz jego współpracownicy zostali usunięci z partii, a w czasie stanu wojennego czasowo internowani.

\section{LITERATURA}

1. II Zjazd PZPR, Warszawa 1954. III Plenum Komitetu Centralnego Polskiej Zjednoczonej Partii Robotniczej (11, 12, 13 listopada 1949 r.), ND 1949 [numer specjalny].

2. Aparat bezpieczeństwa w latach 1944-1956: taktyka, strategia, metody, cz. 2: Lata 1948-1949, oprac. A. Paczkowski, Warszawa 1994.

3. Aparat bezpieczeństwa w Polsce w latach 1953-1954. Taktyka, strategia, metody, wstęp A. Paczkowski, wybór i oprac. G. Majchrzak, A. Paczkowski, Warszawa 2004.

4. Bäcker R, Struktury poziome w Toruniu (1980-1981), Warszawa 1990, passim.

5. Cimek H., Komuniści. Polska. Stalin 1918-1939, Białystok 1990.

6. Dokąd zmierza ta demagogia, „Trybuna Ludu”, 28 XI 1956.

7. Dokumenty do dziejów PRL. Centrum władzy. Protokoły posiedzeń kierownictwa PZPR. Wybór z lat 1949-1970, oprac. A. Dudek, A. Kochański, K. Persak, Warszawa 2000.

8. Dudek A., Obóz władzy w okresie stanu wojennego, „Pamięć i Sprawiedliwość” 2002, nr 2.

9. Dudek A., Ślady PeeReLu. Ludzie, wydarzenia, mechanizmy, Kraków 200.

10. Duraczyński E., PZPR w kryzysie - kryzys w PZPR (lato 1980-lato 1981), „Dzieje Najnowsze" 1997, nr 4.

11. Eisler J., Cykliczne kryzysy władzy - źródta i konsekwencje, „Wiadomości Historyczne” 2000, nr 1.

12. Friszke A., Opozycja polityczna w PRL 1945-1980, Londyn 1994.

13. Gomułka W., Przemówienia. Październik 1956-wrzesień 1957, Warszawa 1959, s. 328.

14. Holzer J., Komunizm w Europie. Dzieje ruchu i systemy władzy, Warszawa 2000.

15. Kołakowski L., Tendencje, perspektywy i zadania, „Życie Warszawy”, 4 II 1957.

16. Lenin W. I., Dzieła wszystkie, t. 41, Warszawa 1988.

17. Lesiakowski K., Mieczystaw Moczar „Mietek”. Biografia polityczna, Warszawa 1998.

18. Lesiakowski K., Emigracja osób pochodzenia żydowskiego z Polski w latach 1968-1969, „Dzieje Najnowsze” 1993, nr 2.

19. List Komitetu Centralnego KPZR do KC PZPR, [5 czerwca 1981 r.], ND 1981, nr 7.

20. List z Moskwy do KC KPRP z 1 lutego 1923 r., AAN, VI Oddz., KPP, mf 728/1.

21. Marzec 1968. Trzydzieści lat później, t. 1, red. M. Kula, P. Osęka, M. Zaremba, Warszawa 1998.

22. Między Wschodem a Zachodem. Studia z dziejów polskiego ruchu i myśli socjalistycznej, red. A. F. Grabski, P. Samuś, Łódź 1995.

23. Morin E., O naturze Związku Radzieckiego, Warszawa 1990.

24. Nicieja S.S., Julian Leszczyński-Leński, Warszawa 1979. 
25. O brakach $w$ pracy partyjnej i środkach zlikwidowania trockistów i innych dwulicowców [referat J. Stalina na Plenum KC WKP(b) 3 III 1937], „Przegląd”, kwiecień 1937 [dodatek].

26. Oblicza Marca 1968, red. K. Rokicki, S. Stępień, Warszawa 2004.

27. Ochab E., Walka trwa, ND 1949, nr 5.

28. Paczkowski A., Aparat bezpieczeństwa w latach odwilży: casus polski, „Zeszyty Historyczne" 1995, z. 114.

29. Pawlikowski L., Tajny front zimnej wojny. Uciekinierzy z polskich stużb specjalnych 1956-1964, Warszawa 2004.

30. Pietrow N., Polska operacja NKWD, „Karta” 1993, nr 11.

31. Poksiński J., „TUN” Tatar-Utnik-Nowicki. Represje wobec oficerów Wojska Polskiego w latach 1949-1956, Warszawa 1992.

32. Popow M., Idealizacja luksemburgizmu - sztandar naszych wrogów, „Orka”, 27 XII 1931.

33. Przemówienie I sekretarza KC PZPR tow. Wtadystawa Gomułki, na spotkaniu z aktywem warszawskim w dn. 19 marca 1968 r., ND 1968, nr 4, s. 23.

34. Skarzyński R., Historia myśli politycznej w ujęciu politologicznym. Zarys koncepcji, „Studia Polityczne" 1992, nr 1.

35. Skarzyński R., Intelektualiści a ideologia. Myśl polityczna jako przedmiot badań politologa, „Studia Nauk Politycznych” 1990, nr 4.

36. Skarzyński R., Wróg i sojusznik. Studium struktury myśli politycznej, „Studia Nauk Polityczny" 1990, nr 1-3.

37. Riepriesii protiw Polakow i polskich grażdan, Moskwa 1997, s. 33.

38. Romek Z., Droga Leszka Kołakowskiego ku antykomunistycznej opozycji. Od ortodoksyjnej ideologii ku wolności myślenia, „Dzieje Najnowsze” 1999, $\mathrm{nr} 4$.

39. Ryng J., Wybór pism, Warszawa 1957.

40. Ryszka F., Poglady na koncepcję państwa, ,Studia Nauk Politycznych” 1984, nr 5.

41. Samuś P., Edward Próchniak, Warszawa 1983.

42. Sobolewska-Myślik K., Partie i systemy partyjne na świecie, Warszawa 2004.

43. Stalin J., Dzieła, t. 6, Warszawa 1951.

44. Stalin J., Dzieła, t. 6, Warszawa 1951.

45. Stobiecki R., Bolszewizm a historia. Próba rekonstrukcji bolszewickiej filozofii dziejów, Łódź 1998.

46. Szyszko M., Ptaszczyzny jedności w partii, „Nowe Drogi” 1983, nr 5.

47. Torańska T., Oni, Warszawa 1989.

48. Trembicka K., Między utopia a rzeczywistością. Myśl polityczna Komunistycznej Partii Polski (1918-1938), Lublin 2007.

49. Trembicka K., Wrogowie i przeciwnicy. Studium myśli politycznej Polskiej Zjednoczonej Partii Robotniczej, Lublin 2013.

50. Ważniewski W., Walka polityczna w kierownictwie PPR i PZPR 1944-1964, Toruń 1991.

51. Wydarzenia kryzysowe w Polsce w latach 1955-1957” (stenogram dyskusji redakcyjnej), „Z Pola Walki” 1982, nr 1-2.

52. Wystapienie Z. Kliszko w czasie XII Plenum KC PZPR, „Nowe Drogi” 1968, nr 8.

53. Zackiewicz G., Polska myśl polityczna wobec systemu radzieckiego 1918-1939, Kraków 2004. 


\section{“ABOUT DEVOURING ITS OWN CHILDREN" ON THE EXAMPLE OF THE ACTIVITIES OF COMMUNIST PARTIES IN POLAND IN THE 20TH CENTURY}

The object of the article is the phenomenon of removing the leaders and politicians of communist parties in Poland from political life in various periods of their activity. In the case of research subjects - the Communist Party of Poland (1918-1938) and the Polish United Workers' Party (1948-1990), it was about eliminating the "most faithful of the faithful" by comrades from the same political environment. It should be stated that the problem of "devouring its own children" was known in history, occurs today and will be present in the future. In the case of communist parties, the phenomenon of "devouring its own children" was influenced by various circumstances: 1) above all, the specificity of the communist parties(these were fundamentalist parties; the Communist Party of Poland operated illegally on the basis of the party-order model), 2) subordination to the external sovereign, which had a decisive influence on the style of political thinking and acting, 3) the processes to which the parties were subjected, i.e. functioning in the conditions of the besieged fortress syndrome and the need for an enemy that allowed to accomplish various goals inside and outside the party, 4) brutal struggle for power which, in the case of the Polish United Workers' Party, allowed to use the state apparatus.

Keywords: "devouring its own children", revolutions, communist parties, heresies, a struggle for power.

DOI: $10.7862 /$ rz.2018.hss.13

Przestano do redakcji: styczeń $2018 \mathrm{r}$. Przyjęto do druku: kwiecień 2018 r. 